\title{
LAPALISSÍADA E VIGARICES
}

\author{
Carlos Eduardo Schmidt Capela \\ UFSC - CNPq
}

\begin{abstract}
RESUMO: Duas breves prosas poéticas assinadas por Manuel Bandeira embasam a intervenção proposta: "Noturno da Rua da Lapa", de Libertinagem (1930), e "0 desmemoriado de vigário geral", de Estrela da manhã (1936). Pensando com elas e a partir delas, mão dadas ao poeta almejo abordar a tensão polar entre um além e um aquém de sentidos. Ou, ainda, entre gestos poéticos e críticos de remissão e omissão.
\end{abstract}

PALAVRAS-CHAVE: Manuel Bandeira; Poemas em prosa; "O desmemoriado de vigário geral"; "Noturno da Rua da Lapa"; Transcriação.

\section{LAPALISSÍADA E VIGARICES}

ABSTRACT: Two short prose poems signed by Manuel Bandeira are based on the proposed intervention: "Noturno da Rua da Lapa", from Libertinagem (1930), and "0 desmemoriado de vigário geral", from Estrela da manhã (1936). Thinking with them and from them, hand in hand to the poet my aim is to approach the polar tension between a beyond and a bellow of senses. Or, still, between poetic and critical gestures of remission and omission.

KEYWORDS: Manuel Bandeira; Prose poems; "0 desmemoriado de vigário geral"; "Noturno da Rua da Lapa"; Transcriation.

Carlos Eduardo Schmidt Capela é professor de Teoria Literária no DLLV e professor do Programa de Pós-Graduação em Literatura da Universidade Federal de Santa Catarina. Pesquisador CNPq. É 0 atual coordenador do Núcleo e Estudos Literários \& Culturais (NELIC). 


\title{
LAPALISSÍADA E VIGARICES
}

\author{
Carlos Eduardo Schmidt Capela
}

\section{A EVOCAÇÃo}

Toda evocação institui uma via de mão-dupla. Emblema da reiteração de fluxos contrastantes, cada uma delas expressa o clássico confronto entre o ir e o vir, este por sua vez acessado a partir de intersecções peculiares. A primeira delas provém de um cruzamento com Søren Kierkegaard, que com um nada de palavras estabelece uma oportuna distinção entre repetição e recordação. Segundo ele ambas realizam "o mesmo movimento, apenas em direção oposta; pois aquilo que se recorda foi, repete-se para trás; enquanto a repetição propriamente dita é recordada para diante". ${ }^{1}$

A observação do filósofo abre a possibilidade de postular uma intrigante diferença no modo como as crianças, de um lado, e os adultos de quem elas são os pais, de outro, tendem a experimentar o exercício da iteração. Os infantes, afinal, com seu insistente clamor por uma "outra vez", ou um "de novo", porventura desejem a repetição para abocanharem um recordo imediato, já que ainda têm pouco a recordar. Quanto aos adultos, eles talvez amem recordar por temor de não mais poderem reiterar. Daí o apreço geral pela repetição, que "se é possível, faz o homem feliz, ao passo que a recordação o faz infeliz".

De um contraponto como tal também a poesia se aproveita. Com seus jogos paronomásticos e suas orquestrações sonoras, potencializados na modernidade pela ênfase nos deslizamentos rítmicos e sensoriais em detrimento dos rígidos enquadramentos métricos e rimáticos, ela permite a homens e mulheres reencontrarem o desprendimento alegre dos petizes que todavia os acompanham. O bem-estar proporcionado pela poética da multiplicação e derivação de singularidades pode, ademais, ser incrementado pelo prazer de deparar, no presente, com eventos pretéritos submetidos a essa mesma lógica do diferimento.

Porque a mnemotecnia das iterações, ao diferi-las, é capaz de fazer oscilar o sentido dos vetores da recordação. Estes, com isso, ao invés de se voltarem unicamente ao passado conseguem apontar para os instantes nos quais arcaicos e arcaísmos não cessam de perpassar o presente. A generalização de Kierkgaard bate então, quase de frente, com a ponderação de Deleuze, para quem a repetição "é simbólica na sua essência; o símbolo, o simulacro, é a le-

${ }^{1}$ KIERKGAARD, Søren. A repetição. Trad. José Miranda Justo. Lisboa: Relógio D’água, 2009, p. 32.

2 Ibidem, p. 32. 
tra da própria repetição. Pelo disfarce e pela ordem do símbolo, a diferença é compreendida na repetição".3

Dado que habita o tempo da palavra, extra-tempo que opera à feição do extra-campo cinematográfico, as vozes poéticas não se furtam de reelaborar no agora o que vem de antes. Intra e extra-versos. Elas impulsionam o anterior para a frente, operação de que resulta sua aptidão de esmigalhar os esquemas lineares, cronológicos e teleológicos. A poesia, destarte, se levada a sério como o é toda brincadeira digna desse nome, jamais deixará de ser pueril.

São várias as provas de que Manuel Bandeira sabia muito bem disso. Uma das mais cabais é o "Porquinho-da-índia", com sua sensibilidade menina espraiada pelas assonâncias que no poema borbulham ao redor de séries de diminutivos e possessivos. O evento poético ali anunciado nasce da rememoração de um fato passado cuja recuperação transcende o epocal, já que o "quando" não mais tido do "tinha" revela-se ao final incontido, incontinente. A pretensa ingenuidade que a presunção adulta atribui à infância quebra a cara ao se deparar com a sofisticação poética subtraída da criancice. O poema não podia portanto ser transcrito senão em technicolor e, não bastando, com o emprego de efeitos diversos:

Porquinho-da-índia ${ }^{4}$

Quando eu tinha seis anos $\quad 1$

anhei um porquinho-da-índia. $\quad 2$

Que dor de coração me dava 3

Porque o bichinho só queria esțar delbaivo do fog a do!

Levava ele prea sala $\quad 5$

$\mathbb{P}$ ra os $\rrbracket$ u ares mais நbonitos mais \impinhos 6

Ele não gostava: $\quad 7$

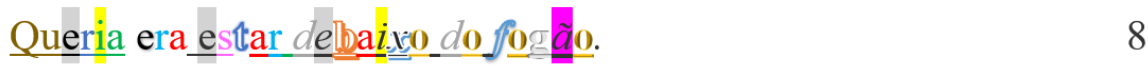

Não fazia caso nenh m das minhas tern urinhas. 9

- O me porquinho-da-índia foi minha primeira namorada. $\quad 10$

${ }^{3}$ DELEUZE, Gilles. Diferença e repetição. Trad. Luiz Orlandi e Roberto Machado. 2. ed Rio de Janeiro: Graal, 2006, p. 41. 
Em vista da limitação na oferta de cores, fundos e grifos na paleta do word, quase insuficientes para realçar a fascinante variação melódica - consonâncias e dissonâncias que apesar de pouco diversificadas animam o poema - , diante de um fato bizarro como este vale indagar, controversando e contraversando: Porque um porquinho? E ainda por cima da índia!?

Esses acordes em 'i' não são acidentais. Colocá-los na conclusão do parágrafo precedente facilita chamar a atenção para a distribuição estratégica destas vogais, que no poema mantêm a vocalidade íntegra na maioria dos casos, já que o papel de apoio, como semi-vogais, é mais exceção que regra. Introduzidas no dístico inicial, elas espocam entre os versos 3, 5 e 7, sua ausência nestes últimos correspondendo à presença do porquinho reduzido a um "ele" impessoal. Após o sétimo verso elas retornam em nítido crescendo conforme o gran finale confessional se avizinha.

Nesse movimento os 'i's apoiam a instigante derivação do possessivo, cujo vigor também obedece uma escala incremental. Se no "minhas" que ecoa em "ternurinhas" o teor de posse é bastante baixo, posto as atitudes ternas visarem a outrem, no "meu" do verso final e no "minhas" que dele deriva a possessão atinge o superlativo. A posição intermédia da forma pronominal masculina, por seu turno, assinala um deslocamento da afeição na direção do feminino: o menino virando homem-macho. Redunda a feminização do objeto de desejo e controle. Em favor da estimação, é verdade, resguardada em que pese à substituição do ser estimado, ou seja, aquele posto sob o jugo de alguém que insiste em impor a seu par uma constante avaliação.

Na cena do poema a meiguice é reforçada pelos diminutivos masculinos, com o "bichinho" do quarto verso ecoando no "limpinhos" do sexto. Já o "porquinho-da-índia" fecha o dístico inicial, além de constituir a referência maior da décima linha. Embora o esquema da sucessão de dois 'i's nasalizados seja nele preservado, o fato de ambos serem nele acentuados faz que o substantivo, ao reaparecer no fechamento do poema, funcione como um invulgar gerador poético.

Essa força tonal dos 'i's nasais, na composição "porquinho-da-índia", é logo depois amortecida pela atonia do 'i' no ditongo 'ia'. Tal alteração acentual no verso final introduz uma contraposição, assaz significativa, com relação ao papel do mesmo encontro vocálico nos verbos no imperfeito do oitavo e nono versos, "Queria" e "fazia", cujos timbres são dominados exatamente pelo 'i'. O

\footnotetext{
${ }^{4}$ BANDEIRA, Manuel. [Porquinho-da-índia, Libertinagem]. Estrela da vida inteira. 8. ed. Rio de
} Janeiro: José Olympio, 1980, p. 100. 
caráter significativo desta ocorrência é pronto percebido caso atentemos para o fato de que tais flexões verbais descrevem as refusões do animal, "primeira namorada" do futuro, com respeito aos quereres manifestos pela voz poética. Elas, em suma, prenunciam inevitáveis embates.

Claro que esse movimento no nível da acentuação nada tem de fortuito, com os jogos sonoros se espalhando do cabo ao rabo do último verso. Mantendo o foco nos 'i's, a perda de força no complemento "índia" se mantém na desinência do perfeito do verbo 'ir', "foi", até ser recuperada, juntamente com o mimo da nasalização, graças ao retorno do possessivo declinado no feminino, "minha". Na sequência os 'i's se repetem outra vez numa só palavra, "primeira". Aí, na ocorrência inicial o 'i' tem a nasalização reduzida a traço e a tonicidade acanhada, processo que culmina em nova redução da vogal ao estatuto de semi-vogal no ditongo 'ei'.

Esse fascinante jogo tonante faz que os 'i's aí aparecidos sete seguidas vezes ajudem a levar adiante as questões acima colocadas: Porque um porquinho? E ainda por cima da índia!?

Como? Atentando ao caráter alusivo, enviesado ou oblíquo, como sói na poética de Bandeira. Que no fechamento do poema os esparrama de modo a incumbi-los de coordenar o distendimento de um encadeamento murmurante no qual nasalizações alternam com a pronúncia normal, isso num ambiente lexical fortemente nasalizado. Resulta um 'in-in-ia-oi-in-i-ei', sequência que evoca a entoação de um mantra, o clássico coral indiano de sagração acabando assim por se transformar em um canto amerindiano.

A súbita transição do afeto por um bichinho para a afeição por uma amada não agraciada com o carinho diminutivo acarreta uma transferência da disjunção. A princípio fundada na separação entre hominídeos e caviídeos de um mesmo gênero, a distinção é deslocada para as diferenças de gênero no âmbito de uma única espécie. Esse processo, cujo ápice coincide com a conclusão do poema, é antecipado pela sequência dos 'a's do quinto verso, "Levava ele pra sala”, em que os priápicos 'l's e as invaginações dos ' $v$ 's sintetizam o drama que resultará na polarização masculino-feminina projetada sobre a "primeira namorada" da décima linha.

Único isento de nasalizações, o quinto verso, ademais, é justo aquele no qual o sujeito do poema começa a listar os esforços despendidos no afã de fazer a criatura estimada satisfazer a desejos dele exclusivos. A cadeia de 'a's reaparece dois versos abaixo antes de retornar nas palavras finais do poema, quando atuam de maneira decisiva. Pois os 'a's nelas instaladas interrompem 
o desenrolar do mantra amerindiano, reinstalando com isso o conflito desdobrado entre os versos 5 e 9 . O enfrentamento característico das relações entre seres apartados aparece assim encalacrado de antemão na morada, antes de ser estendido para a "primeira namorada" encarnada pelo porquinho.

Face a tamanha destreza poética só resta, por ora, arriscar um trocadilho. Que talvez alegrasse o poeta: esse Bandeira não dá bandeira mesmo! A bem da poesia, inda bem.

Mas há que acrescentar: a bem de uma poesia para lá de requintada. Portanto, ao invés de reiterar a aparente humildade do escritor, ou a enganosa simplicidade de seus poemas, exuberantes lugares comuns em boa parte da fortuna crítica que deles se ocupa, penso ser mais estimulante continuar a destacar a presença, nesse poeminha dotado de uma brandura tão infantil, beirando o piegas, de um trabalho escritural cujo alto nível está intimamente ligado a um surpreendente poder de gestar combinações vocabulares prenhes de expressividade.

Arranjos nos quais sensual, ou musical, não deixa de rimar com social, rima essa que de pobre nada tem. Desde o acento colocado sobre o "quando" criança não é difícil nele discernir, seja numa clave política, histórica ou psicanalítica, a presença incômoda do inevitável confronto de subjetividades inerente ao mito edulcorado do amor burguês, muito mal dito quando qualificado simplesmente "romântico", já que ele carrega consigo algumas das dissimetrias que há tempos perduram nessas nossas Sul-Américas no momento mais e mais norteadas.

O porquinho que canta a madura voz poética é responsabilizado por ter trazido dó de peito à criança em quem ela outrora vibrou, cujas impressões relativas a determinados acontecimentos são extraídas daquele então. Para tanto o poeta propõe uma sugestiva disposição temporal, na qual uma imediata alternância entre o pretérito imperfeito e o perfeito que o segue, na parelha inaugural, antecede um conjunto de sete linhas cujos verbos estão todos no imperfeito, fluência só interrompida com a volta repentina do perfeito do verso final. Graças a tal organização a "dor de coração" antes restrita à meninice é projetada para a persona do homem-feito construída pelo texto.

Essa projeção ganha o suplemento gráfico do espaçamento e do travessão, responsáveis por introduzir a confissão culminante que em sua circunscrição pontual absorve o processual então em curso. O princípio corriqueiro em enredos fabulares, nos quais animais são amiúde antropomorfizados, resumido na fórmula era uma vez, a que se segue a narração de acontecimentos de 
quando o eu "tinha seis anos", é não sem brusquidez abortado por um ríspido "foi". Trazendo consigo uma informação avessa ao contexto até ali imperante, o verbo rasura a idealizada magia do universo infantil e, de chofre, alude à atmosfera marrenta predominante nas relações amorosas entretidas por toda a gente orgulhosa de ser grande.

À gaiata declaração terminal cabe também o papel de reabrir o ciclo da repetição, já que a mera referência a uma dada namorada de quem se diz ter sido a "primeira" implica em admitir, mesmo em sub-repção, a existência de uma segunda, quiçá uma terceira, etc. Até o traço do travessão, ao ser com capricho partido para assim espaçar a palavra-chave do texto, o reiterado "porquinho-da-índia", sugere a teimosa iteração de situações afetivas similares àquela condensada no poema, pautadas todas por um tenso equilíbrio que transita entre os extremos da entrega e da resistência.

A narrativa poética deixa claro que o resgate adulto de uma presumida memória infantil conta com o resguardo do acúmulo de experiências proporcionadas pelo correr dos anos. Em função disso a lembrança surge menos enquanto uma recordação nua e crua, estabilizada ou resolvida, que como uma releitura de eventos antes ocorridos, efetuada a posteriori, cujo concernimento abarca o futuro do menino de quem fala o homem. Reencenado pela linguagem e ressuscitado no instante da enunciação, o passado que teima em jamais parar de passar é não apenas atualizado como intervém de maneira categórica para o desenlace elíptico do enunciado. A brusca suspensão que o encerra abre o campo ao suspense: mesmo silente o mantra regressa. $E$ vinga.

Henri Bergson, Gilles Deleuze e David Lapoujade, entre outros estudiosos de inevitáveis relações entre os consoantes conceitos de memória e história, atribuem expressiva importância a este procedimento posto em ação no poema, que na literatura brasileira tem como antecedente um dos relatos antológicos de Machado de Assis, "Missa do galo" (ai, ai, esses animais cujos nomes não cansam de assombrar!). Também nesse conto o eu que se assenhora da palavra para falar de um episódio de antanho, relativo a um possível envolvimento passional, aparece inelutavelmente rachado, dividido em quando menos duas partes em larga medida assindéticas.

Natural, então, a predominância, no poema, de uma atmosfera volteando entre brandas frustação e melancolia. Tal clima é afiançado pelo acento posto sobre o dó do peito, a aguda nota melódica que qual o mal-agradecido porquinho obstinada não transige. Ambos são assim finamente conjugados para fulgurarem a persistente desobediência da criatura amada - esta sem- 
pre outrem, inclusive se inumana -, que recusa permanecer nos espaços a ela atribuídos, selecionados pelo amante de ocasião a cujos comandos deveria forçosamente se submeter.

O fato de a criatura ter sido "ganhada" pelo infante merece ser salientado. A doação por um lado oferece a ele a oportunidade de começar a aprender a amar, árduo tirocínio do qual cartilha alguma consegue dar conta. Por outro lado, e mais relevante, o detalhe do regalo faculta à voz poética realçar, lamentando-a, a descabida insubmissão por parte do ser a que se devota, cuja posse é ressaltada pelos possessivos. Em decorrência do desprezo aos pedidos e vontades por ele reclamados, a pomposa sala e os "lugares mais bonitos mais limpinhos" da Casa Grande se surpreendem humilhados pela opção escandalosa por querer "estar debaixo do fogão", anunciada no quarto verso e repetida no oitavo. A preferência pelo chão da cozinha, verdadeira extensão da Senzala, mais que perturba: escandaliza.

Mas o pior, que está por vir e súbito (mais um subitâneo explodindo nesse poema povoado de repentes) invade a consciência do homem que se lembra menino, é que tal predileção não se restringia à rejeição a gentilezas e oferecimentos. Do bicho querido, com efeito, é afirmado que não fazia "caso nenhum" das ternas "ternurinhas" recebidas. Amargo, o diagnóstico acaba com o jogo, se de jogo se tratasse, uma vez que o em hipótese alguma não admite réplica.

A única solução, então, é partir em busca de um outro ser que acate ordens e compartilhe afagos, que aceite ou se conforme em ser mandado. Como há pouco assinalado, o porquinho, namorada primeira, apenas encabeça uma possível sequência na qual sucessivos fracassos têm sucesso, tal encadeamento também permanecendo implícito nesse poema que além de tudo embute a história emblemática de um país, em miniatura. A belíndia-brazil, cuja porção indiana não só persevera como necessita ser ampliada, não em território, claro, o que justifica o presente fortalecimento da ordem judicial-policialesca em prol da defesa dos interesses dos auto-proclamados "homens de bem", bem cuja medida é diretamente proporcional aos bens materiais ou imateriais amealhados.

No espaço poético, de todo modo, o namoro transitivo com outrem pressupõe a intransitiva paixão demandada pela língua. Desse envolvimento que embrulha os demais resulta a inevitabilidade de se conformar com a impossibilidade de alcançar, de modo imediato, verdades ou essências de seja lá o que for. Em tal domínio, afinal, predomina uma 
negatividade em que o acesso se faz o que ele é: isso que deve ceder, e, para isso, de saída deve se esquivar, se recusar. $O$ acesso é difícil, não é uma qualidade acidental: isso quer dizer que a dificuldade faz o acesso. $O$ difícil é o que não se deixa fazer, e é propriamente o que a poesia faz. Ela faz o difícil. ${ }^{5}$

A poesia não é uma fêmea de vida fácil, o poema não é um macho de vida fácil - justo eles que namorar vale a pena. Conquanto desafiantes, porquanto.

\section{A VICÁRIA VENTURA DO VIGÁRIO}

À evocação se segue uma constatação inicial:

- Bandeira escreveu bastante sobre o próprio trabalho. É sua a autoria de um dos livros exemplares acerca de exercícios e motivações poéticas que teriam resultado em alguns dos mais celebrados poemas que deram sobrevida a seu nome: Itinerário de Pasárgada. Publicá-lo constituiu um gesto louvável, sem dúvida, isso a despeito dos efeitos colaterais daí decorrentes, à revelia embora. Porque se quase todos os críticos que se debruçaram sobre sua produção dele emprestaram depoimentos e apontamentos para referendar ou referenciar análises por eles elaboradas, o que nada tem de problemático, uma parte nada desprezível dentre estes estudiosos, contudo, utilizou afirmações do poeta como chaves de leitura, às vezes exclusivas, imediatamente aplicadas a textos que deveriam com cuidado escrutinar, o que é no mínimo temerário. Um círculo vicioso tende assim a se estabelecer, no qual observações de um autor sobre seus poemas são tomadas como premissas, ou imperativos, para sustentar a proposição de interpretações que em boa medida se limitam a reafirmar aquilo de antemão por ele afirmado. Ao clássico biografismo, pelo qual a vida não só explica como molda a arte, sobrepõe-se então um elã algo brochante de atestar o atestado, isso em prejuízo da movência inerente à poesia, cujo poder de repercussão para-além-da-vida-imediata acaba deste modo estagnado. Ou melhor, dado o contexto, esterilizado.

O exercício "desconstelizador" que segundo Haroldo de Campos perpassa a poesia do "operador rebelde" Manuel Bandeira é desta maneira, e não sem ironia, depreciado graças ao apagamento daquele limite que seus poemas não se eximem de cruzar. Daquela

\footnotetext{
${ }^{5}$ NANCY, Jean-Luc. Fazer, a poesia. In: Demanda: literatura e filosofia. Trad. João Camillo Penna et. al. Florianópolis / Chapecó: EDUFSC/Argos, 2016, p. 146.
} 
linha sutil que separa o lugar comum (a redundância, a frase feita, o clichê da sensibilidade) da informação original, e que faz muitas vezes que, por uma simples mudança de ângulo de enfoque e/ou de âmbito contextual, o que é redundante passe a produzir essa informação nova; melhor esclarecendo: a informação estética de certos poemas bandeirianos... nasce do deslocamento repentino, fiado numa fímbria de linguagem apenas, do lugar comum para o lugar incomum. ${ }^{6}$

Essa primeira constatação deságua numa outra:

- são raros os estudos acerca de poemas em prosa da lavra de Bandeira, em que pese ao fato de eles, embora poucos, clamando existirem. Além deste, um segundo motivo para estudá-los seria a possibilidade de rediscutir ou tensionar o propalado prosaísmo conferido a seus poemas "normais", versados ou conversados, isso para não falar da força poética que tais exceções excessivas atestam. A percepção de certo estado de coisas embutida nessa constatação complementar alimenta esse ensaio.

E como se trata de destrinchar tecidos poéticos nada melhor que partir de uma passagem da coletânea que reúne um conjunto de ensaios firmados por um dos principais estudiosos da poesia de Bandeira, senão o principal: Humildade, paixão e morte: a poesia de Manuel Bandeira, de Davi Arrigucci Jr. Uma das poucas menções diretas a poemas em prosa cifrados pelo poeta aparece já no capítulo inicial do livro. Nele, após ter identificado uma aguda convergência entre as imagens poéticas dispostas em "Maçã", de um lado, e imagens pictóricas presentes em diversas telas de Cézanne nas quais tal gênero de fruta é motivo central, de outro, o crítico toma essa "analogia evidente com a pintura" enquanto "uma tendência poderosa para a composição na forma da natureza-morta"7, que julga inerente à produção literária do escritor.

Na sequência o fazer poético de Bandeira é sumarizado, com o aval da conhecida "Introdução" de Gilda de Mello Souza e de Antonio Candido à Estrela da vida inteira. A composição de naturezas-mortas verbais é considerada por Arrigucci uma técnica que

lembra o fracionamento cubista da realidade exterior, com sua visão por lados diversos, conforme se dá nos primeiros versos de "Maçã" ou no retrato de mulher de "Peregrinação". Certamente, a retomada de elementos anteriores, por assim dizer "desrealizados", num contexto novo, arbitrário e às vezes insólito, faz pensar sobretudo na técnica da montagem surrealista, discreta mas profundamente ar-

${ }^{6}$ CAMPOS, Haroldo de. Bandeira, o desconstelizador. In: Metalinguagem e outras metas. 4. ed. São Paulo: Perspectiva, 1992, p. 111.

7 ARRIGUCCI JR., Davi. Ensaio sobre "Maçã" (Do sublime oculto). In: Humildade, paixão e morte: a poesia de Manuel Bandeira. São Paulo: Cia das Letras, 1990, p. 29. Os realces são meus. 
raigada em Bandeira, sempre tão sensível à poesia do onírico, do ilógico, do absurdo e do nonsense. Basta recordar poemas como o "Noturno da Parada Amorim" ou a insólita revelação do "Noturno da Rua da Lapa", e tantos outros. ${ }^{8}$

Talvez entre esses incertos "tantos outros" poemas aludidos no final do parágrafo conste "O desmemoriado de vigário geral", adiante aqui discutido, já que o trânsito entre um procedimento qualificado como "cubista" e um outro posto sob o influxo da "montagem surrealista" acarreta a seleção de exemplos bastante distintos em termos de organização poética. Os dois primeiros poemas mencionados, com efeito, são dispostos em versos, enquanto dos dois últimos o "Noturno da Rua da Lapa" é um poema em prosa, e "Noturno da Parada do Amorim", embora versificado, possui um tom acentuadamente prosaico. Na medida em que o ensaio prossegue sem que nada acerca dessa relações entre princípios de elaboração artística e princípios de composição poética seja esclarecido, é possível supor que um quiasma teórico e analítico é ali sugerido mas não devidamente esclarecido, e tampouco explorado.

Num capítulo ulterior o autor volta a tratar da montagem, de novo vista como "uma tendência tão fundamental e geral do trabalho do poeta". 9 Ele então a redefine, com o resguardo de um previdente "talvez",

\begin{abstract}
[...] como uma tendência para o que se poderia chamar de assemblage livre, transformando-se depois propriamente em montagem (às vezes, em colagem), como um princípio geral e recorrente de construção, quando então o poeta opera com mais desenvoltura os materiais, deslocando arbitrariamente elementos de um determinado contexto primário para um contexto novo no âmbito do poema, criando uma lógica interna própria entre esses elementos de repente aproximados, modificados e harmonizados, independentemente das contradições e contrastes que mantenham entre si, tornando possível uma síntese do diverso, modo de encerrar, numa unidade determinada, o universal. ${ }^{10}$
\end{abstract}

\footnotetext{
8 Ibidem, p. 29 [realces meus]. O diagóstico será em larga medida mantido em ensaio posterior do autor, no qual assinala que, "por vezes, Bandeira se aproximaria assim da técnica de construção cubista, de recortes simplificadores e geometrizantes do real, fazendo confluir percepções contrastantes e simultâneas de um mesmo objeto; ou da montagem surrealista, recombinando em misturas insólitas esferas diversas da realidade, minada pelo onírico, pelo absurdo ou pelo nonsense. Na verdade, era herdeiro ainda da atitude libertária dos românticos, radicalizada pelas vanguardas que, no caminho de Baudelaire, se lançaram à pesquisa lírica através das mesclas mais variadas, do sublime ao abjeto, do mais prosaico ao elevado, dilatando o espaço da poesia até as margens da impureza e do reconhecimento de novas e inesperadas dimensões da sensibilidade poética." Idem, A beleza humilde e áspera. In: O cacto e as ruínas: A poesia entre outras artes. 2. ed. São Paulo: Duas Cidades / Ed. 34, 2000, p. 18.

9 Idem, A visão alumbrada. In: Humildade, paixão e morte: a poesia de Manuel Bandeira, op. cit., p. 141.

10 Ibidem [realces meus].
} 
Parte dos fundamentos teóricos e críticos que suportam o empreendimento analítico de Arrigucci nos ensaios de Humildade, paixão e morte assomam resumidos na passagem, no qual são expostos com singular transparência. Fica claro que o que mais lhe importa, ao menos nessa coletânea, é determinar unidades, instituir congruências ou conformidades entre os elementos contextuais e os objetos presentes nos poemas, isto é, as palavras, e articulá-los segundo um modelo sintático-sintético pautado pela coerência, logicamente cerrado, no qual sons e sentidos estejam muito bem ajustados às referências a eles imputadas. Para tanto, apesar de mencionadas as "contradições e contrastes" são postas de lado, consideradas resolvidas pelo próprio escritor. Os textos poéticos, enfim, são pensados como totalidades conjuminadas, como unidades de um corpo ordenado cujos órgãos operam em perfeita harmonia.

Pensado e executado nestes termos, o procedimento analítico acaba por dar corpo aos poemas, a incorporá-los, o que leva a uma flagrante atenuação de um dos seus mais instigantes atributos: o de conseguir imaginar o infigurável, e por conseguinte encarná-lo, propriedade sobre a qual Marie-José Mondzain discorre em $A$ imagem pode matar? Na medida em que viabiliza o invisível, ou pelo menos ao imaginá-lo o torna sensível, a poesia adquire o excêntrico poder de formar, "muito precisamente, uma imagem da paixão". ${ }^{11} \mathrm{~A}$ encarnação, para Mondzain, assegura uma pluralização de pontos de vista e, em decorrência, introduz a possibilidade de contraposições. Ela produz dissonâncias além de consonâncias. Porque encarnar

não é imitar, nem reproduzir, nem simular. [...] Encarnar é dar carne e não dar corpo. É operar na ausência das coisas. A imagem dá carne, isto é, carnação e visibilidade, a uma ausência, mediante uma diferença intransponível relativamente àquilo que é designado. Dar corpo, pelo contrário, é incorporar, é propor a substância consumível de qualquer coisa de real e de verdadeiro aos convivas que se fundem e desaparecem no corpo com que se identificam. [...] Na incorporação somos apenas um, na imagem encarnada constituem-se três instâncias indissociáveis: o visível, o invisível e o olhar que os coloca em relação. A imagem pertence a uma estranha lógica do terceiro excluído. ${ }^{12}$

Não deixa de ser também sintomático que Arrigucci, ao vincular certa faceta do trabalho poético de Bandeira à montagem surrealista e à fragmentação cubista, não se atenha, por exemplo, ao "método paranoico crítico"

${ }^{11}$ MONDZAIN, Marie-José. A imagem pode matar? Trad. Susana Mouzinho. Lisboa: Nova Vega, 2009, p. 25-26.

12 Idem, p. 26. 
de Salvador Dali, com sua "simulação do delírio", que nas palavras de Eliane Robert Moraes "viria a contribuir para o descrédito total da realidade". ${ }^{13} \mathrm{~A}$ própria concepção surrealista das coisas, que "supõe a eclosão de significados completamente novos quando os objetos são deslocados de seu quadro habitual", ${ }^{14}$ colide frontalmente com a proposta universalista subscrita pelo crítico. Não é por acaso, portanto, que este se abstenha de analisar poemas em prosa de Bandeira, e se limite a apresentá-los como ilustrações de uma "poesia do onírico, do ilógico, do absurdo e do nonsense".

Em outros termos: Arrigucci exila de seu corpus de estudo exatamente modalidades de fazer poético que curto-circuitam, que interrompem as cadeias usuais de significação. Uma vez rasurados os sentidos e despedaçados os modelos de significação estereotipados, elas, com isso, facultam às modulações sonoras de palavras e versos ressaltarem, potencializadas. Junto ao particular arranjo poético olvidado é ainda desprezada a questão de ouvido implicada no domínio poético, no qual nem sempre é possível garimpar sentidos ou vagar em busca de significações, mas onde sempre se pode permanecer à escuta. Descolada do logos, música não discursa, e muito menos procura ou faz sentido. Para responder a ela há que senti-la, de algum modo, e quem sabe dançá-la.

Onírico, ilógico, absurdo e nonsense: esses quatro termos apenas aludidos na primeira das passagens de Arrigucci antes transcritas apontam para uma única coisa. Tal coisa é a própria impossibilidade de dizê-los fora do espaço, com seus campos de força, que criam em torno de si mesmos, posto que todos, além de paradoxais, mostram-se avessos a se deixarem subordinar ao estreito binarismo do verdadeiro ou do falso. Eles afirmam seu sem sentido, e este é seu sentido.

Fiquemos aqui com o nonsense, nome que segundo Deleuze doa sentido, que por seu turno constitui "sempre um efeito. Não somente um efeito no sentido causal; mas um efeito no sentido de 'efeito óptico', 'efeito sonoro', ou melhor, efeito de superfície, efeito de posição, efeito de linguagem". ${ }^{15} \mathrm{O}$ nonsense "não possui nenhum sentido particular, mas se opõe à ausência de sentido e não ao sentido que ele produz em excesso sem nunca manter com

\footnotetext{
${ }^{13}$ MORAES, Eliane Robert. O corpo impossível: a decomposição da figura humana de Lautréamont a Bataille. São Paulo: FAPESP/Iluminuras, 2002, p. 47.

${ }^{14}$ Idem, p. 48.

${ }^{15}$ DELEUZE, Gilles. Lógica do sentido. Trad. Luiz Roberto Salinas Fortes. 4. ed. São Paulo: Perspectiva, 2003, p. 73.
} 
seu produto a relação simples de exclusão à qual gostaríamos de reduzi-lo". ${ }^{16}$ Nele, que "é ao mesmo tempo o que não tem sentido, mas que, como tal, opõe-se à ausência de sentido", em suma, "o sentido não é nunca princípio ou origem, ele é produzido". ${ }^{17}$

Em "O desmemoriado de vigário geral" Manuel Bandeira se entrega ao fascínio do nonsense, e se diverte com ele. E como não poderia deixar de ser, fala sobre o poema, bem en passant, no Itinerário de Pasárgada. Ouçamos o que dele nos diz:

Quero assinalar em certa página da Estrela da manhã mais uma influência: "O desmemoriado de vigário geral" não teria sido escrito daquele jeito e naquela forma se eu não tivesse lido certo poema em prosa de Pedro Dantas, publicado na revista Verde, de Cataguazes; creio que se intitulava "Uma aventura". O que me encantou nele foi o mistério que o poeta soube insuflar numas tantas locuções trivialíssimas. Lembro-me desta, por exemplo: “Azul-marinho, dirão vocês. Porém nem sempre". ${ }^{18}$

O poeta se equivoca duas vezes: na autoria atribuída ao poema, assinado não por Pedro Dantas, pseudônimo de Prudente de Moraes, Neto, mas por este; e no próprio nome do texto a que se refere, cujo título é simplesmente "Aventura". Mas quase acerta na mosca a passagem que rememora. Ei-lo, com o acréscimo do grifo azul sobre a dita passagem, tal como publicado no terceiro número de Verde, uma das revistas do Modernismo da primeira hora:

Aurora, voz de estranhos céos, aurora, que amargor naquele gesto largo das montanhas! As casas desse momento, tão isoladas, imagine que davam para uma grande pedra multiforme. Ruas e mais ruas precipitavam-se em torno do succedido. $\mathrm{E}$ os últimos acontecimentos eram de natureza principalmente calcarea como se diz. Eis que de repente o povo irrompe em enthusiasmo. Foi quando silenciosamente as horas uma a uma se puseram a fugir.

Daí a uma tentativa compreende-se que havia um passo ou dois. Assim sendo a segunda hipótese reconhecidamente mais saudável teve a audácia de desaparecer por um caminho desses que a gente não percorrerá jamais. A um certo signal, e como si todos estivessem ligados a uma idéa fixa todos os homens tremeram, enquanto as mulheres e as palavras mais hábeis riam riam perdidamente. A scena se repetiu três vezes. E por absurdo que pareça, nem todo mundo desistiu de conciliar o sono. $\mathrm{O}$ sono ao contrario é que tomou maior numero de iniciativas. Percebendo a manobra atrevida não tive duvida em contemplar pessoalmente as

16 Idem, p. 74.

17 Idem, respectivamente p. 64 e 75 (realce meu).

18 BANDEIRA, Manuel. Itinerário de Pasárgada, Rio de Janeiro: Nova Fronteira / INL, s/d; p. 102. 
nuvens face a face. De todos os lados protestos intrínsecos faziam que sim com as mãos, os pés e algumas orelhas.

Isso porem nunca seria motivo bastante para eu não florir ou amortecer.

Ao contrario. Bem me parecia que a intransigência daquela pobre gente significava alguma coisa mais do que um simples compasso. Compasso? Desses assim eu vi muitos. Quantas vezes calaram-se os gansos, não, pergunte só quantas vezes calaram-se antes dele ser isso. Azul marinho, dirão vocês. Mas nem sempre. Outrora sim, reconheço e como negar que assim fosse por um espaço superior ao capitão? Franqueza das franquezas e que milhor coisa ha que não dure o tempo necessario a tais emanações? Não. Eu vi. Depois de mim que vieram as estrelas. Oh! sem aquele sabor de antigamente, que as fazia tão altas e vacilantes nos seus cantares. Assim como quem diz que a vida está fora de discussão. ${ }^{19}$

Trata-se quiçá de um exemplo da "ateologia poética" de que fala Giorgio Agamben, "singular coincidência de niilismo e prática poética" através da qual "a poesia se transforma no laboratório em que todas as figuras conhecidas são desarticuladas para dar lugar a novas criaturas para-humanas ou subdivinas". ${ }^{20}$ Prudente de Moraes, Neto, assume em seu texto uma maneira de dispor o coleamento poético em que uma "desapropriação" e um "não-pertencimento" com relação a um estilo específico contamina o próprio modo de organizar as sequencialidades. Assuntos, nomes e atributos, referências, relações e ilações lógicas encontram-se desapropriadas, são tornadas impróprias, embora expostas por intermédio de uma sintaxe rigorosa, absolutamente impecável.

O autor demonstra por um lado aderir "a um uso ou a um modelo (estereotipia, repetição)". ${ }^{21}$ Por outro lado, porém, impõe a eles um excesso, no caso, o excesso do absurdo. As estruturas usuais que sustentam o edifício do sentido destruídas, sobrevivem imagens e sons, no modo das ruínas, ou alegorias. É esta maneira, ou maneirismo, que Manuel Bandeira glosa, sem pudor algum, em "O desmemoriado de vigário geral", exemplo de elevada sensibilidade no trato com a linguagem, de sua invejosa habilidade em ouvi-la. E em errar por seus meandros, como os ratos que seguem não o flautista de Hamelin mas o sopro virado som livrado pela flauta:

\footnotetext{
${ }^{19}$ MORAES, NETO, Prudente, Aventura. Verde (Revista Mensal de Arte e Cultura), Cataguazes, Minas Gerais, Anno 1, Numero 3, p. 14, nov. 1927;

${ }^{20}$ AGAMBEN, Giorgio. Desapropriada maneira. Categorias italianas: estudos de poética e literatura. Trad. Carlos E. S. Capela e Vinícius N. Honesko. Florianópolis: EDUFSC, 2014; p. 119.

${ }^{21}$ Idem, p. 126.
} 
Lembravalase como se fosse ontem, isto ê, hă quallenta sécullos, que um exército de pirâmides o contemp】ava. Mas não saberian precisar onde, al que luz ou em que so】de que extinta constelação. Não obstante preferia que fosse na estrela mais branca do cinturão de Orion.

蛋 verdade: havia uma muiher que telefonaval. Mas não distante, meu Deus, que eran como se The faltasse al ella e paral todo o sempre um atributo humano indispensấlvel.

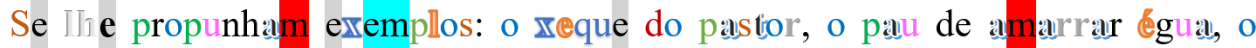
mal-assombrado de Guapi, futura cidade, ele dissimulavia. IEran então horrlvell de se ver. alventura band. ${ }^{22}$

Ifinall um dia foi encontrado morto e quando jă nem tudo era possível, uma

A vigarice do vigário geral: mostrar que a ausência de versos não desapropria o poético. Isso num poema improvável, amalucado, no qual gotículas de referências à suposta "realidade" podem contudo ser sorvidas: as pirâmides diante de um Napoleão neófito, as "três Marias" do cinturão de Órion, o próprio Órion que persegue as filhas de Pleione, as Plêiades, assim como alguns críticos perseguem sentidos de poemas, e pior, acreditam poder desencavá-los.

Não é possível encontrar muito mais que isso, pois o resto é poeira em suspensão, amparada por diferentes modalidades de nasalização, por sibilações e vibrações, por rimas e aliterações, por paronomásias e assonâncias diversas.

"Afinal", o texto, além de proporcionar muito mais que "uma aventura banal", traz em seu bojo um manifesto exemplar. Não modernista ou vanguardista, porém em prol, ou melhor, em louvor da poesia, a poesia qualquer.

Quiçá como tal jamais escrito.

\section{LAPALISSÍADA}

Se em Paris a "Place Clichy", nome um tanto quanto sugestivo, é no dizer de Paulo Prado o "umbigo do mundo" oswaldiano, ${ }^{23}$ a Lapa, bairro boêmio da cidade do Rio de Janeiro, pode por seu turno ser tida como o aleph de Manuel

${ }^{22}$ BANDEIRA, Manuel. O desmemoriado de vigário geral. In: Estrela da manhã, Estrela da vida inteira, op. cit., p. 123.

${ }^{23}$ A referência consta do prefácio escrito por Paulo Prado para Pau-Brasil, a primeira coletânea de poemas publicada por Oswald de Andrade, em 1925. A passagem aludida é essa: "Oswald de Andrade, numa viagem a Paris, do alto de um atelier da Place Clichy - umbigo do mundo descobriu, deslumbrado, a sua própria terra". PRADO, Paulo. Poesia Pau-Brasil. In: ANDRADE, Oswald, Pau-Brasil, Obras completas - VII - Poesias reunidas. 5. ed. Rio de Janeiro: Civilização Brasileira, 1978, p. 67. 
Bandeira. As noitadas que atravessam toda sua Libertinagem ecoam, com efeito, no "Noturno da Rua da Lapa". Disso o poeta é testemunha. Quando afirma, por exemplo:

\begin{abstract}
Libertinagem contém os poemas que escrevi de 1924 a 1930 - os anos de maior força e calor do movimento modernista. Não admira, pois, que seja entre os meus livros o que está mais dentro da técnica e da estética do modernismo. Isso todo o mundo pode ver. $\mathrm{O}$ que no entanto poucos verão é que muita coisa que ali parece modernismo, não era senão o espírito do grupo alegre de meus companheiros diários naquele tempo: Jaime Ovalle, Dante Milano, Oswaldo Costa, Geraldo Barrozo do Amaral. Se não tivesse convivido com eles, de certo não teria escrito, apesar de todo o modernismo, versos como os de "Mangue", "Na boca", "Macumba de Pai Zuzé", "Noturno da Rua da Lapa" etc. (este último é aproveitação de um caso que se passou com Ovalle em sua casa da Rua Conde de Lage"). ${ }^{24}$
\end{abstract}

Similar ao que fazem as palavras - que remetem umas às outras, mostrando com isso não possuírem nem partido e nem posição absoluta, ocupando apenas lugares mutuamente relativos, logo provisórios -, poemas têm o pendor de remeter a poemas, e textos quaisquer a quaisquer outros textos. Tudo depende da vontade de quem pode, e quer, ao escrever, aludir a tais ou quais originais. E da vontade de quem pode, e quer, ao ler os escritos, identificar e navegar as alusões.

É também assim que sentidos, miríades deles, podem ser tramados em tecidos, sem esquecer entretanto que estes podem ainda ser esgarçados, rasgados ou recortados. Uma tal propriedade, ou atributo, compartilham os textos todos com a vida, outro provisório, descontínua e ademais periclitante. Sempre, entrementes, enredada a incontáveis outras.

Além dos diversos jogos sintáticos-sonoros nele dispostos, o "Noturno da Rua da Lapa" espalha referências ao redor de si, e em seu seio acolhe, de modo até escancarado, textos e contextos exógenos. No momento, todavia, importa sublinhar a disposição fônica e rítmica do poema, fracionado em cinco parágrafos repletos de nasalizações intercaladas por sons abertos proporcionados pelos 'é's, 'ó's e 'á's nele disseminados:

${ }^{24}$ BANDEIRA, Manuel. Itinerário de Pasárgada, op. cit., p. 91. [Realce meu]. 
A jancla estaval ajoertal. Para o que não sei, mas o que entrava eran o vento dos luparares, de mistura com o eco que se parrial as curvans cicloidais, e fragmentos do hilo da bondeira.

Não posso atian ho que eu faial se meditavala, se morria de espanto ou se hal de muito longe.

Nesse momento (oh! por que precisamente [esse momento?...) é que penetr u

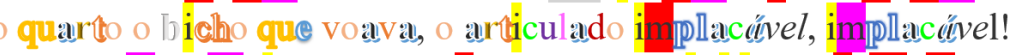

Compreendi desde logo ão haver possi ilidade enhuma de evasão. Nascer de

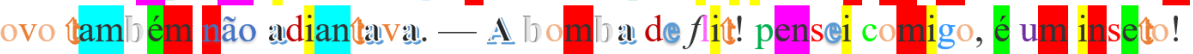

Quando o jacțo fumigatorio partiu, a ada mudou em mim; os sipos da redenção continuaram em silêncio; Denhuma porta se abriu nem feehou. Mas o molturuoso animal FICOU MA IOR. Senti que ele fão morreria nuncan mais, nem sairian,

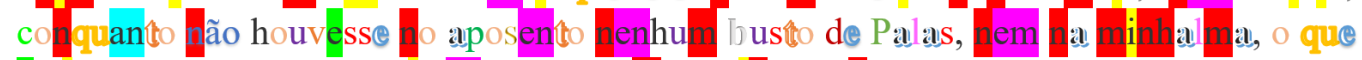
é pior, a recordação persisutente de al guma extinta Lenora. 25

Súbito, o texto principia com uma asserção indicativa de um estado de coisas que do mundo imediato ricocheteia sobre o sujeito: a janela descerrada pressupõe uma passagem pela qual exterior e interior se comunicam, mas ao mesmo tempo sugere a vigília de quem a observava, indicação assegurada pelo pretérito imperfeito. O complemento no princípio da frase seguinte esclarece acerca da inexistência de propósito, ou quando menos da ignorância do eu lírico em relação ao que poderia advir da conjuntura na qual recorda ter estado inserido. A confissão traduzida pelo "não sei" introduz a primeira de uma série de negações e expressões negativas em torno das quais o poema se organiza.

Através dela, que reverbera no "não posso" encabeçando o período subsequente, a reflexão é situada no presente, o dito de agora tendo como referência acontecimentos outrora ocorridos, esquema presente também no "Porquinho-da-índia", como visto. Recuperados pela memória, os eventos são apresentados em três movimentos. A tripartição de frases e parágrafos, procedimento persistentemente reiterado ao longo do relato, é complementada por repetições ternárias de alguns vocábulos nele cruciais, de acepção negativa, como o "não" acima reportado (que aparece seis vezes), o pronome indefinido "nenhum(a)" e o advérbio "nem" (cada um com três ocorrências). A estes se soma a conjunção "se", cujo encadeamento triádico, no segundo parágrafo, instaura a atmosfera hipotética que antecede as fortes marcações temporais do terceiro e do quinto segmentos, quando o "Noturno da Rua da

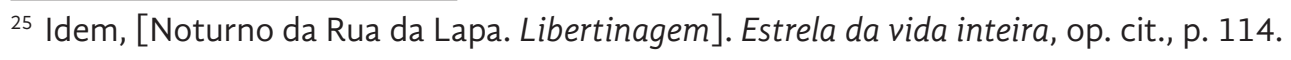


Lapa" dá as costas à realidade, à concretude do quarto e de seu além, e inflecte na direção do espaço literário, tornado então principal responsável pela sensificação e subjetivação da persona que fala o poema.

No prosseguimento do parágrafo inaugural (seria possível chamá-lo verso, ou estrofe?), dada a insciência manifesta resta a esta persona o apelo às sensações físicas, que desdobram informações relativas ao que Ihe chegava de fora. O vento a entrar no aposento principia a tríade trazendo consigo eflúvios sensuais, posto provir "dos lupanares". A ausência de referência aos embora presentes odores do sexo é compensada pela menção a ressonâncias. Se o registro do "hino da bandeira" pode ser depositado na conta da galhofa antinacionalista, a alusão ao "eco", cuja reverberação é assegurada pelas rimas toantes constantes em pela "janela... aberta", de par com o "era" que o antecede, situa de chofre o texto no campo da intertextualidade, da qual a canção patriótica é apenas o segundo exemplo.

Pois no "eco" ecoa a própria Eco, a ninfa apaixonada por Narciso, personagens do Livro III das Metamorfoses, de Ovídio. A partir daí nos surpreenderemos à deriva no oceano encrespado da repetição diferida. Antes de tentar singrá-lo convém lembrar que tanto Eco quanto Narciso são infelizes em seus amores, o sentimento de frustração atravessando todo o "Noturno da Rua da Lapa".

O prosseguimento deste segundo motivo reserva um novo assombro, prenúncio do morrer "de espanto" que adiante advirá: o "eco" que "se partia" sofre a divisão apenas quando passa pelas "curvas cicloidais". A inflexão pisca o olho, enigmática. E é preciso recorrer ao dicionário para saber que o adjetivo "cicliodal" remete ao substantivo "cicloide", que não só nomeia uma forma geométrica como se refere à "ciclotimia", um tipo de personalidade na qual intervalos de euforia e desprendimento alternam com outros de tristeza e inatividade. Tal padrão é característico da melancolia, tema de enorme importância na cultura ocidental. Sobre ele Albrecht Dürer se debruçou, para ficar com um exemplo célebre que faz parte de um variado e consistente acervo intelectual. A presença oblíqua da melancolia decerto antecipa as futuras incursões do poema em textos da tradição literária, no caso de Franz Kafka e Edgar Allan Poe.

A sombra do autor tcheco começa a ser mais bem delineada com a chegada do próximo parágrafo, cuja termo de abertura é uma negação relativa ao fato de o eu lírico não poder agora "atinar", isto é, recordar ou se dar conta do que então "fazia". A insciência persistente pode ser declinada como um desbarate, o negativo descortinando a trinca de hipóteses estabelecidas a partir da partícula "se", de teor dubitativo. As opções são em si desbaratadas: "se 
meditava", hábito típico dos melancólicos, se "morria de espanto" sem causa extratextual aparente, ou se "vinha", não de longe porém "de muito longe", expressão vaga que abarca distanciamento no espaço ou no tempo. A excêntrica proliferação de todo modo assinala um descompasso do sujeito consigo mesmo, seu inexorável pendular. Em busca de sentidos inevitavelmente perdidos no paiol abarrotado de significações e comoções transitivas?

A atmosfera de suspensão e suspense conflui na única sentença da qual o advérbio de negação não participa. Mesmo a marcação temporal, a princípio nela resoluta, é todavia relativizada pelo questionamento posto entre parênteses, cuja formulação roça o lugar-comum romântico. Seja como for algo finalmente acontece: a invasão do quarto por um bicho voador, caracterizado pela implacabilidade e pelo fato de ser "articulado". É evidente o contraste entre a desarticulação até o momento demonstrada pela voz poética e o atributo da articulação lançada sobre inseto. Decerto que a propriedade articulatória é inerente à linguagem, e é justo a dificuldade do sujeito de articular em si e por si a linguagem que possibilita a instalação do amplo espectro de referência textuais com as quais o poema vai sendo entretecido.

A chegada do inseto demarca a instalação da dominância do pretérito perfeito, só interrompida por dois casos de imperfeito, um no indicativo e outro no subjuntivo. Ela ainda prepara o terreno para a entrada do quarto parágrafo, no qual o "compreender" afasta momentaneamente o desbaratamento, que no entanto positiva uma cadeia de negações que será mantida até o fechamento do texto. A ambiguidade é incrementada pela ironia relativa àquilo recém compreendido. De um lado o "não haver possibilidade nenhuma de evasão", expressão em que fuga e subterfúgio se confundem, inclusive com respeito aos rodeios com os quais referências intertextuais são entrecruzadas. De outro o paradoxo do "nascer de novo", que em nada modifica o jugo do destino acentuado no parênteses. ${ }^{26}$

${ }^{26}$ Durante a preparação da edição anterior do Boletim (vol. 18, n 30 ), ao ler o "Rondó do atribulado do Tribobó" citado no instigante ensaio de Jorge Wolff, "Joaquim Bandeira: jogos onomásticos e nova gnomonia", eis que para minha surpresa e contentamento deparei com uma versão quase idêntica desta mesma concatenação de constatações, atenuada pela eliminação do pronome indefinido e do advérbio, na abertura de outros parênteses que retornam, nesse caso concluindo o poema: "(Não havia possibilidade de evasão / Nascer de novo não adiantava / ...)". Essa retomada de um dístico de um livro publicado em 1930 no poema saído na Joaquim, 28 anos depois, abre a possibilidade de que outros volteios nos quais distintos textos se enlaçam possam ser ensaiados. Considerando o relato exposto em Itinerário de $\mathrm{Pa}$ sárgada, a "aproveitação de um caso que se passou com Ovalle na sua casa da Rua Conde de Lage" se projeta sobre a descrição da atribulada aventura na calorenta chácara fluminense que teria ocorrido com Joaquim Pedro de Andrade. Retomando um conceito lembrado no ensaio de Jorge Wolff (que encontra no "Rondó do atribulado de Tribobó" ainda um outro caso de auto-plágio proveniente de mais um poema em prosa, "Noturno da parada Amorim"), aqui também defrontamos a "Realidadeficçãa". 
A tripartição é retomada neste parágrafo, cujo terceiro termo é ele mesmo segmentado em três partes, além de ser precedido por um travessão que o coloca à parte. O padrão tradicional que vai da percepção, ou constação, passa pela reflexão e culmina numa solução, ou resolução, aparece aí invertido. Tal inversão nada tem de acessória, posto estabelecer a ocasião em que a prostração melancólica será substituída por uma ação direta, cujo objetivo é responder à ameaça representada pela invasão do bicho voador no espaço íntimo do sujeito. Ela embute um processo de reversão através do qual a evoção proveniente de Ovídio explode em Kafka, as Metamorfoses singularizadas em A metamorfose.

O período final, o mais longo e complexo, mantém a estrutura tripartida, composta no caso por sentenças completas. A primeira delas responde de maneira elíptica à atitude deixada em suspenso no parágrafo anterior, o recurso à bomba de inseticida. Abrupto, o "quando" ordena, desde uma perspectiva posterior, três eventos paralelos que sucedem à dispersão do veneno. A flexão negativa permanece em todos desdobramentos, que demarcam o retorno da inação melancólica que dá lugar ao devaneio. A pronta intervenção em "nada" altera o sujeito, os sinos se mantém silentes, as portas continuam como estavam.

Reinstalado, o desbaratamento atinge seu nível mais alto na segunda sentença, o que é visualmente indicado pelo enunciado em caixa-alta, "FICOU MAIOR", referente ao "animal" já a princípio qualificado como "monstruoso". O crescimento do invasor, o "bicho que voava", anuncia a mudança de referência. Esta abandona o kafkiano Gregor Samsa, que ao devir inseto se transformara em corpo estranho na casa da família pequeno-burguesa, situação só resolvida com sua morte, para se encarnar no corvo de Edgar Allan Poe, a "ave ou bicho" proveniente "dos bons tempos ancestrais" 27 que não mais sairá do quarto, e cujo premonitório "nunca mais" será para sempre ouvido nas noites da boêmia Rua da Lapa.

Definitivamente arruinada no enunciado final, a causalidade aparta de uma vez por todas o poema do ambiente fenomenal. Nada mais que textos e criaturas verbais nele assomam. O movimento do foco, que a partir do imperfeito do subjuntivo passeia pelo aposento no qual nenhum busto de Palas Atena, dona de sóbrias determinação e sabedoria, pode ser divisado (embora

${ }^{27}$ As citações são da tradução de Fernando Pessoa de O corvo, de Edgar Allan Poe. PESSOA, Fernando, O corvo, Poemas traduzidos para o português. Obra poética. Rio de Janeiro: José Aguilar, 1974, p. 631-633. 
paradoxalmente o seja), acaba por devassar a intimidade do eu. O sujeito que ao narrar se narra revela ser alguém que se "sentiu" perseguido não apenas por suas inexistentes frustrações amorosas. No seu caso não se trata de "nunca mais", de um "never more", mas de jamais. De jamais "Lenora" e jamais lembranças de outras paixões. Ele literalmente experimenta uma situação ainda mais desoladora que a da personagem do "O Corvo".

A transfiguração de Manuel Bandeira alcança o prodígio de potencializar o "efeito" poético que Poe afirma ter buscado em seu poema, em "A filosofia da composição", "com a precisão e a sequência rígida de um problema matemático." ${ }^{28} \mathrm{O}$ "efeito de linguagem", que para Deluze atravessa o nonsense, torna-se um evento sobretudo literário baseado em uma anterior exposição literária, esta por sua vez, etc., etc. Em suma: a repetição diferencial persevera.

A "melancolia [...], o mais legítimo de todos os tons poéticos", ${ }^{29}$ segundo Poe, permanece convergindo para a "Morte". O "mais melancólico dos temas", contudo, no caso não se aplica à "morte de uma bela mulher". ${ }^{30} \mathrm{O}$ assunto "mais poético do mundo" passa a ser, no original de Bandeira, a inexistência ou impossibilidade do próprio amor, pois nele a paixão por outrem não vinga. A metamorfose ali perpetrada permite que a situação proposta por Poe seja levada adiante: o ser ou razão de ser do arrebatamento passional vem à luz como um feto natimorto, cuja morte fora desde o princípio anunciada pelo "vento dos lupanares", local da baixa prostituição que faz do amor e da entrega simples mercadoria. Neste cenário no qual a tragédia moderna é encenada, literatura e artes teimam em resistir, acenando com o presente da palavra a um mundo mais e mais votado à solidão, à esterilidade e ao aniquilamento.

A poesia prosaica ou a prosa poética do "Noturno da Rua da Lapa" preserva ritmos, timbres, tons e compassos que modulam e melodiam a linguagem. Os sons nele evolam, e em seu voo carregam os sentidos, para longe, seja no tempo, seja no espaço literários. No território em que a poesia espraia não há com efeito omissões. Remissões porém enxameiam.

\footnotetext{
${ }^{28}$ POE, Edgar Allan. A filosofia da composição. In: Poemas e ensaios. Trad. Escar Mendes e Milton Amado. Rio de Janeiro: Globo, 1985, p. 103.

29 Idem, p. 105.

30 Idem, p. 107.
} 